\title{
ISO/IEC 15504 measurement applied to COBIT process maturity
}

\author{
Alastair Walker \\ SPI Laboratory (Pty) Ltd, Johannesburg, South Africa \\ Tom McBride \\ University of Technology, Sydney, Australia \\ Gerhard Basson \\ Old Mutual, Cape Town, South Africa \\ Robert Oakley \\ T-Systems South Africa (Pty) Ltd, Johannesburg, South Africa
}

\begin{abstract}
Summary: The assessment of COBIT process maturity levels for each COBIT process is fraught with many problems regarding the objectivity of the end result. This paper attempts to align the generic aspects of the COBIT 4.1 process maturity scale with the concepts of the Process Attributes of the ISO/IEC 15504-2 measurement scale. The goal behind this alignment attempt is to be able to automatically convert ISO/IEC 15504 assessment profile data captured for processes into their equivalent COBIT process maturity rating, to identify where there is no equivalent process assessment data and to propose how these gaps might be overcome. The end result of this computation of COBIT process maturity levels is to be able to assert that the assessed level is traceable to objective underlying assessment profile data gathered and rated according to the normative requirements of ISO/IEC 15504-2.
\end{abstract}

\section{Introduction}

The assessment of COBIT process maturity levels (ITGI, 2007) for a COBIT process is fraught with many problems regarding the objectivity of the end result.

Unlike ISO/IEC 15504, COBIT does not define a rigorous assessment model. The descriptive content is limited to defining the process maturity levels together with behavioural characteristics associated with a set of six process attributes.

This paper presents a new method for aligning the behavioural aspects of the six COBIT process attributes with achievement results defined for the nine process attributes associated with the ISO/IEC 15504-2 (ISO, 2003b) measurement scale.

This alignment permits a translation of the ISO/IEC 15504 assessment profile data captured for the assessed processes into an appropriate COBIT process maturity rating, for each selected process.

A valuable result of this computation of COBIT process maturity levels is that we can demonstrate that the end result (i.e. COBIT process maturity level) is traceable and verifiable against objective evidence gathered during the assessment.

\section{Challenges associated with rating COBIT process maturity levels}

One of the underlying reasons that the COBIT process maturity model is difficult to assess is that key terms (i.e. process capability, process maturity) are not specifically defined. Within COBIT, process capability is considered a subset of process maturity whereas in ISO/IEC 15504 process capability is a measure of an individual process and maturity is a measure of organizational performance associated with a collection of processes.

A reason advanced for not defining an assessment model appears to be a concern regarding the degree of 'granularity'. An assessment model that is too granular is considered too costly to apply. Consequently, users of this model need to define their own assessment model (Simonsson, 2007), or assemble one based on the profile of concerns in the process maturity model description associated with each process (Pederiva, 2003).

The COBIT process maturity model defines general behavioural characteristics associated with each process maturity level. The process maturity model behavioural characteristics are tailored for each COBIT process to the specific needs of the process. 


\section{Process capability measurement in the ISO/IEC 15504 context}

ISO/IEC 15504-2 identifies the minimum requirements for performing an assessment that ensures consistency and repeatability of the ratings. The requirements help to ensure that the assessment output is self-consistent and provides evidence to substantiate the ratings and to verify compliance with the requirements.

Within this measurement framework, the measurement of capability is based upon a set of process attributes (PA). Each attribute defines a particular aspect of process capability. The extent of process attribute achievement is characterized on a defined rating scale. The combination of process attribute achievement and a defined grouping of process attributes together determine the process capability level. The nine process attributes are:

1) PA 1.1 Performed

2) PA 2.1 Performance management

3) PA 2.2 Work product management

4) PA 3.1 Defined

5) PA 3.2 Deployed

6) PA 4.1 Measurement

7) PA 4.2 Controlled

8) PA 5.1 Innovation

9) PA 5.2 Optimised

The extent of achievement of a process attribute is measured using an ordinal scale of measurement as defined in Table $\mathrm{XI}$ in Annex A. Each process attribute is rated based on validated data. During an assessment a defined set of indicators in the process assessment model is used to support the assessors' judgement in rating process attributes in order to provide the basis for repeatability. There is an obligation to record the decision-making process that is used to derive ratings, and to maintain traceability between an attribute rating and the objective evidence used in determining that rating.

Each process attribute is supported by a definition and a set of 'achievement results'. For example, for PA 2.1 Performance Management:

\begin{tabular}{|l|l|}
\hline \multicolumn{1}{|c|}{ Definition } & \multicolumn{1}{c|}{ Achievement results } \\
\hline $\begin{array}{l}\text { The performance } \\
\text { management attribute is a } \\
\text { measure of the extent to } \\
\text { which the performance of } \\
\text { the process is managed. }\end{array}$ & $\begin{array}{l}\text { As a result of full achievement of this attribute: } \\
\text { a) objectives for the performance of the process are identified; } \\
\text { b) performance of the process is planned and monitored; }\end{array}$ \\
& $\begin{array}{l}\text { d) responsibilities and authorities for performing the process are defined, assigned and } \\
\text { communicated; } \\
\text { e) resources and information necessary for performing the process are identified, made } \\
\text { available, allocated and used; } \\
\text { f) interfaces between the involved parties are managed to ensure both effective } \\
\text { communication and also clear assignment of responsibility. }\end{array}$ \\
\hline
\end{tabular}

Although each process attribute definition is supported by a set of 'achievement results', there is no obligation to record (intermediate) ratings for each achievement result.

To assist assessors, generic practices are defined in each assessment model that provide further detail for each process attribute achievement result.

For example, in ISO/IEC 15504-5 (ISO, 2005) the following generic practices are defined for PA 2.1 a). 


\begin{tabular}{|l|l|}
\hline \multicolumn{1}{|c|}{ Process attribute achievement result } & \multicolumn{1}{c|}{ Generic practice 2.1.1 } \\
\hline $\begin{array}{l}\text { PA 2.1 a) objectives for the performance of the process } \\
\text { are identified; }\end{array}$ & $\begin{array}{l}\text { GP 2.1.1 Identify the objectives for the performance of the } \\
\text { process. } \\
\text { Performance objectives are identified based on process } \\
\text { requirements. } \\
\text { The scope of the process performance is defined. } \\
\text { Assumptions and constraints are considered when } \\
\text { identifying the performance objectives. }\end{array}$ \\
\hline
\end{tabular}

The assessment model also provides guidance regarding sources of process evidence that will support each generic practice.

Although this level of detail in the assessment model might appear overly elaborate, it does help to provide a basis for conducting assessment that provides consistent assessment results.

\section{Alignment of COBIT process attributes to ISO/IEC 15504-2 process attribute achievement results}

The ISO/IEC 15504 model for process capability assessment addresses a considerably wider range of concerns than those described in the COBIT process attributes. Some of the ISO/IEC 15504 process attribute achievement results are strongly aligned to the concerns identified in the COBIT process attribute behaviour descriptions.

The COBIT process attributes include:

1) Responsibility \& Accountability

2) Awareness \& Communication

3) Policies, Plans \& Procedures

4) Tools \& Automation

5) Skills \& Expertise

6) Goal Setting \& Measurement

The tables in the sections that follow each identify a COBIT process attribute, the applicable ISO/IEC 15504 process attribute achievement results, and a proposed aggregated rating that pertains to the selected achievement results.

Tables II to VII each identify one or more ISO/IEC 15504 process attribute achievement results that need to be rated according to the scale in Table IX. This rating (i.e. N, P, L or F) then identifies the matching COBIT definition. For example, in Table II, the ISO/IEC 15504 rating of Largely is associated with a COBIT process attribute rating of Level 3 (i.e. Process responsibility and accountability are defined and process owners have been identified. The process owner is likely to have full authority to exercise the responsibilities.)

The identification of process attribute achievement results from ISO/IEC 15504-2 and rating judgements (i.e. N, P, L or F) associated with the CoBIT process maturity level (i.e. 1 to 5) bring together the essence of the proposed alignment between the COBIT and ISO/IEC 15504 reference frameworks.

\subsection{Performed process (CPA 1) ${ }^{1}$}

The COBIT process maturity model does not make specific reference to the performance of the control objectives for each process in the description of the COBIT process attribute behaviour descriptions. This omission is considered to be a serious weakness of the process maturity model. In view of this, specific reference is made to the technical coverage of the control objectives for each process. The equivalent ISO/IEC 15504 process attributes is termed 'Process Performance'. The ratings definitions are simply those listed in the table in Annex A.1.

${ }^{1}$ CPA refers to 'COBIT Process Attribute - in order to distinguish it from PA (ISO/IEC 15504 Process Attribute). 


\begin{tabular}{|l|l|c|}
\hline \multicolumn{2}{|c|}{ Table I Process performance } \\
\hline $\begin{array}{l}\text { COBIT process attribute } \\
\text { ISO/IEC 15504-2 Attribute } \\
\text { achievement result }\end{array}$ & Process Performance (Not defined specifically in COBIT) & \begin{tabular}{c} 
ISO/IEC \\
\hline \multicolumn{1}{|c|}{ ISO/IEC $\mathbf{1 5 5 0 4}$ Definition }
\end{tabular} \\
\hline $\begin{array}{l}\text { There is little or no evidence of achievement of the defined attribute in the assessed process. } \\
\text { There is some evidence of an approach to, and some achievement of, the defined attribute in the }\end{array}$ & N \\
\hline $\begin{array}{l}\text { assessed process. Some aspects of achievement of the attribute may be unpredictable. } \\
\text { There is evidence of a systematic approach to, and significant achievement of, the defined attribute in } \\
\text { the assessed process. Some weakness related to this attribute may exist in the assessed process. }\end{array}$ & L \\
\hline $\begin{array}{l}\text { There is evidence of a complete and systematic approach to, and full achievement of, the defined } \\
\text { attribute in the assessed process. No significant weaknesses related to this attribute exist in the } \\
\text { assessed process. }\end{array}$ & F \\
\hline
\end{tabular}

\subsection{COBIT process attribute: CPA 2 Responsibility and accountability}

The COBIT concerns associated with 'responsibility and accountability' are addressed in ISO/IEC 15504 in three process attributes, PA 2.1, 3.1 and 3.2. The applicable achievement results are listed in the table below.

\begin{tabular}{|c|c|c|c|}
\hline \multicolumn{4}{|c|}{ Table II Responsibility and accountability } \\
\hline COBIT process attribute & \multicolumn{3}{|l|}{ Responsibility and accountability } \\
\hline $\begin{array}{l}\text { ISO/IEC 15504-2 Attribute } \\
\text { achievement result }\end{array}$ & \multicolumn{3}{|c|}{$\begin{array}{l}2.1 \mathrm{~d} .1 \text { ) responsibilities and authorities for performing the process are defined and } \\
\text { assigned; } \\
2.1 \mathrm{f} .1 \text { ) interfaces between the involved parties are managed to ensure clear } \\
\text { assignment of responsibility. } \\
\text { 3.1 c) required competencies and roles for performing a process are identified as part } \\
\text { of the standard process; } \\
\text { 3.2 b) required roles, responsibilities and authorities for performing the defined } \\
\text { process are assigned and communicated; }\end{array}$} \\
\hline \multicolumn{2}{|r|}{ COBIT Definition } & $\begin{array}{l}\text { COBIT Process } \\
\text { Maturity level }\end{array}$ & $\begin{array}{c}\text { ISO/IEC } \\
\text { 15504 Rating }\end{array}$ \\
\hline \multicolumn{2}{|c|}{$\begin{array}{l}\text { There is no definition of accountability and responsibility. People take } \\
\text { ownership of issues based on their own initiative on a reactive basis. }\end{array}$} & 1 & $\mathrm{~N}$ \\
\hline \multicolumn{2}{|c|}{$\begin{array}{l}\text { The individual assumes his/her responsibility and is usually held accountable } \\
\text { even though this is not formally agreed. There is confusion about responsibility } \\
\text { when problems occur and a culture of blame tends to exist. }\end{array}$} & 2 & $\mathrm{P}$ \\
\hline \multicolumn{2}{|c|}{$\begin{array}{l}\text { Process responsibility and accountability are defined and process owners have } \\
\text { been identified. The process owner is likely to have full authority to exercise the } \\
\text { responsibilities. }\end{array}$} & 3 & $\mathrm{~L}$ \\
\hline \multicolumn{2}{|c|}{$\begin{array}{l}\text { Process responsibility and accountability are accepted and working in a way } \\
\text { that enables a process owner to fully discharge his/her responsibilities. A } \\
\text { reward culture is in place that motivates positive action. }\end{array}$} & 4 & $\mathrm{~F}$ \\
\hline \multicolumn{2}{|c|}{$\begin{array}{l}\text { Process owners are empowered to make decisions and take action. The } \\
\text { acceptance of responsibility has been cascaded down throughout the } \\
\text { organization in a consistent fashion. }\end{array}$} & 5 & $\mathrm{~F}$ \\
\hline
\end{tabular}




\subsection{COBIT process attribute: CPA 3 Awareness \& Communication}

The COBIT concerns associated with 'awareness and communication' are addressed in ISO/IEC 15504 in process attribute PA 2.1. The applicable achievement results are listed in the table below.

\begin{tabular}{|c|c|c|c|}
\hline \multicolumn{4}{|c|}{ Table III Awareness and communication } \\
\hline COBIT process attribute & \multicolumn{3}{|l|}{ Awareness \& Communication } \\
\hline $\begin{array}{l}\text { ISO/IEC 15504-2 Attribute } \\
\text { achievement result }\end{array}$ & \multicolumn{3}{|c|}{$\begin{array}{l}2.1 \mathrm{~d} .2 \text { ) responsibilities and authorities for performing the process are communicated; } \\
2.1 \mathrm{e} \text { ) resources and information necessary for performing the process are identified, } \\
\text { and made available; } \\
2.1 \mathrm{f} .2 \text { ) interfaces between the involved parties are managed to ensure effective } \\
\text { communication. }\end{array}$} \\
\hline \multicolumn{2}{|r|}{ COBIT Definition } & $\begin{array}{l}\text { COBIT Process } \\
\text { Maturity level }\end{array}$ & $\begin{array}{l}\text { ISO/IEC } \\
\text { 15504 Rating }\end{array}$ \\
\hline \multicolumn{2}{|c|}{$\begin{array}{l}\text { Recognition of the need for the process is emerging. There is sporadic } \\
\text { communication of the issues }\end{array}$} & 1 & $\mathrm{~N}$ \\
\hline \multicolumn{2}{|c|}{$\begin{array}{l}\text { There is an awareness of a need to act. Management communicates the overall } \\
\text { issues. }\end{array}$} & 2 & $\mathrm{P}$ \\
\hline \multicolumn{2}{|c|}{$\begin{array}{l}\text { There is understanding of the need to act. Management is more formal and } \\
\text { structured in its communications. }\end{array}$} & 3 & $\mathrm{~L}$ \\
\hline \multicolumn{2}{|c|}{$\begin{array}{l}\text { There is understanding of the full requirements. Mature communication } \\
\text { techniques are applied and standard communication tools are in use. }\end{array}$} & 4 & $\mathrm{~F}$ \\
\hline \multicolumn{2}{|c|}{$\begin{array}{l}\text { There is advanced, forward-looking understanding of the requirements. } \\
\text { Proactive communication of issues based on trends exists, mature } \\
\text { communication techniques are applied and integrated communication tools are } \\
\text { in use. }\end{array}$} & 5 & $\mathrm{~F}$ \\
\hline
\end{tabular}

\subsection{COBIT process attribute: CPA 4 Policies, Plans \& Procedures}

The COBIT concerns associated with 'awareness and communication' are addressed in ISO/IEC 15504 in process attribute PA 3.1. The applicable achievement result is listed in the table below.

\begin{tabular}{|c|c|c|c|}
\hline \multicolumn{4}{|c|}{ Table IV Policies, Plans \& Procedures } \\
\hline COBIT process attribute & \multicolumn{3}{|l|}{ Policies, Plans \& Procedures } \\
\hline $\begin{array}{l}\text { ISO/IEC 15504-2 Attribute } \\
\text { achievement result }\end{array}$ & \multicolumn{3}{|c|}{$\begin{array}{l}3.1 \text { a) a standard process, including appropriate tailoring guidelines, is defined that } \\
\text { describes the fundamental elements that must be incorporated into a defined process. }\end{array}$} \\
\hline \multicolumn{2}{|r|}{ COBIT Definition } & $\begin{array}{l}\text { COBIT Process } \\
\text { Maturity level }\end{array}$ & $\begin{array}{l}\text { ISO/IEC } \\
15504 \text { Rating }\end{array}$ \\
\hline \multicolumn{2}{|c|}{$\begin{array}{l}\text { There are ad hoc approaches to processes and practices. The processes and } \\
\text { policies are undefined. }\end{array}$} & 1 & $\mathrm{~N}$ \\
\hline \multicolumn{2}{|c|}{$\begin{array}{l}\text { Similar and common processes emerge, but are largely intuitive because of } \\
\text { individual expertise. Some aspects of the process are repeatable because of the } \\
\text { individual expertise. Some documentation and informal understanding of policy } \\
\text { and procedures might exist. }\end{array}$} & 2 & $\mathrm{P}$ \\
\hline \multicolumn{2}{|c|}{$\begin{array}{l}\text { Usage of good practices emerges. The processes, policies and procedures are } \\
\text { defined and documented for all key activities. }\end{array}$} & 3 & $\mathrm{~L}$ \\
\hline \multicolumn{2}{|c|}{$\begin{array}{l}\text { The process is sound and complete; internal best practices are applied. All } \\
\text { aspects of the process are documented and repeatable. Standards for } \\
\text { developing and maintaining the processes and procedures are adopted and }\end{array}$} & 4 & $\mathrm{~F}$ \\
\hline
\end{tabular}




\begin{tabular}{|l|c|c|}
\hline followed. Policies have been approved and signed off by management. & & \\
\hline $\begin{array}{l}\text { External best practices and standards are applied. Process documentation is } \\
\text { evolved to automate workflows. Processes, policies and procedures are } \\
\text { standardised and integrated to enable end to end management and }\end{array}$ & 5 & F \\
improvement. & & \\
\hline
\end{tabular}

\subsection{COBIT process attribute: CPA 5 Tools \& Automation}

The COBIT concerns associated with 'tools and automation' are addressed in ISO/IEC 15504 in three process attributes, PA 2.1, 3.1 and 3.2. The applicable achievement results are listed in the table below.

\begin{tabular}{|c|c|c|c|}
\hline \multicolumn{4}{|c|}{ Table VTools and automation } \\
\hline COBIT process attribute & \multicolumn{3}{|l|}{ Tools \& Automation } \\
\hline $\begin{array}{l}\text { ISO/IEC 15504-2 Attribute } \\
\text { achievement result }\end{array}$ & \multicolumn{3}{|c|}{$\begin{array}{l}2.1 \text { e) resources and information necessary for performing the process are identified, } \\
\text { made available, allocated and used; } \\
3.1 \mathrm{~d} \text { ) required infrastructure and work environment for performing a process are } \\
\text { identified as part of the standard process; } \\
3.2 \mathrm{~d} \text { ) required resources and information necessary for performing the defined } \\
\text { process are made available, allocated and used; } \\
\text { 3.2 e) required infrastructure and work environment for performing the defined } \\
\text { process are made available, managed and maintained; }\end{array}$} \\
\hline \multicolumn{2}{|r|}{ COBIT Definition } & $\begin{array}{l}\text { COBIT Process } \\
\text { Maturity level }\end{array}$ & $\begin{array}{l}\text { ISO/IEC } \\
15504 \text { Rating }\end{array}$ \\
\hline \multicolumn{2}{|c|}{$\begin{array}{l}\text { Some tools may exist; usage is based on standard desktop tools. There is no } \\
\text { planned approach to the tool usage. }\end{array}$} & 1 & $\mathrm{~N}$ \\
\hline \multicolumn{2}{|c|}{$\begin{array}{l}\text { Common approaches to use of tools exist but are based on solutions developed } \\
\text { by key individuals. Vendor tools may have been acquired but are probably not } \\
\text { applied correctly and may even be shelfware. }\end{array}$} & 2 & $\mathrm{~N}$ \\
\hline \multicolumn{2}{|c|}{$\begin{array}{l}\text { A plan has been defined for use and standardization of tools to automate the } \\
\text { process. Tools are being used for their basic purpose but may not be in } \\
\text { accordance with the agreed plan and may not be integrated with one another. }\end{array}$} & 3 & $\mathrm{P}$ \\
\hline \multicolumn{2}{|c|}{$\begin{array}{l}\text { Tools are implemented according to a standardized plan, and some have been } \\
\text { integrated with other related tools. Tools are being used in main areas to } \\
\text { automate management of the process and monitor critical activities and controls. }\end{array}$} & 4 & $\mathrm{~L}$ \\
\hline \multicolumn{2}{|c|}{$\begin{array}{l}\text { Standardized tool sets are used across the enterprise. Tools are fully integrated } \\
\text { with other related tools to enable end-to-end support of the processes. Tools } \\
\text { are being used to support improvement of the process and automatically detect } \\
\text { control exceptions. }\end{array}$} & 5 & $\mathrm{~F}$ \\
\hline
\end{tabular}

\subsection{COBIT process attribute: CPA 6 Skills \& Expertise}

The COBIT concerns associated with 'skills and expertise' are addressed in ISO/IEC 15504 in two process attributes, PA 3.1 and 3.2. The applicable achievement results are listed in the table below.

\begin{tabular}{|c|c|}
\hline \multicolumn{2}{|r|}{ Table VI Skills and expertise } \\
\hline COBIT process attribute & Skills \& Expertise \\
\hline $\begin{array}{l}\text { ISO/IEC 15504-2 Attribute } \\
\text { achievement result }\end{array}$ & $\begin{array}{l}3.1 \text { c.1) required competencies for performing a process are identified as part of the } \\
\text { standard process; } \\
3.2 \text { c) personnel performing the defined process are competent on the basis of } \\
\text { appropriate education, training, and experience. }\end{array}$ \\
\hline
\end{tabular}


Table VI Skills and expertise

\begin{tabular}{|c|c|c|}
\hline \multicolumn{3}{|l|}{ Table VI Skills and expertise } \\
\hline COBIT Definition & $\begin{array}{l}\text { COBIT Process } \\
\text { Maturity level }\end{array}$ & $\begin{array}{l}\text { ISO/IEC } \\
15504 \text { Rating }\end{array}$ \\
\hline $\begin{array}{l}\text { Skills required for the processes are not identified. A training plan does not exist } \\
\text { and no formal training occurs. }\end{array}$ & 1 & $\mathrm{~N}$ \\
\hline $\begin{array}{l}\text { Minimum skills requirements are identified for critical areas. Training is provided } \\
\text { in response to needs, rather than on the basis of an agreed plan and informal } \\
\text { training on the job occurs. }\end{array}$ & 2 & $\mathrm{P}$ \\
\hline $\begin{array}{l}\text { Skill requirements are defined and documented for all areas. A formal training } \\
\text { plan has been developed, but formal training is still based on individual } \\
\text { initiatives. }\end{array}$ & 3 & $\mathrm{~L}$ \\
\hline $\begin{array}{l}\text { Skill requirements are routinely updated for all areas, proficiency is ensured for } \\
\text { all critical areas, and certification is encouraged. Mature training techniques are } \\
\text { applied according to the training plan, and knowledge sharing is encouraged. } \\
\text { All internal domain experts are involved, and the effectiveness of the training } \\
\text { plan is assessed. }\end{array}$ & 4 & $\mathrm{~F}$ \\
\hline $\begin{array}{l}\text { The organization formally encourages continuous improvement of skills based } \\
\text { on clearly defined personal and organizational goals. Training and education } \\
\text { support external best practices and the use of leading-edge concepts and } \\
\text { techniques. Knowledge sharing is an enterprise culture, and knowledge based } \\
\text { systems are being deployed. External experts and industry leaders are used for } \\
\text { guidance. }\end{array}$ & 5 & $\mathrm{~F}$ \\
\hline
\end{tabular}

\subsection{COBIT process attribute: CPA 7 Goal Setting \& Measurement}

The COBIT concerns associated with 'goal setting and measurement' are addressed in ISO/IEC 15504 in three process attributes, PA 2.1, 3.1 and 3.2. The applicable achievement results are listed in the table below.

\begin{tabular}{|c|c|c|c|}
\hline \multicolumn{4}{|c|}{ Table VII Goal setting and measurement } \\
\hline COBIT process attribute & \multicolumn{3}{|l|}{ Goal Setting \& Measurement } \\
\hline $\begin{array}{l}\text { ISO/IEC 15504-2 Attribute } \\
\text { achievement result }\end{array}$ & \multicolumn{3}{|c|}{$\begin{array}{l}2.1 \text { a) objectives for the performance of the process are identified; } \\
\text { 3.1 e) suitable methods for monitoring the effectiveness and suitability of the process } \\
\text { are determined. } \\
\text { 3.2 f) appropriate data are collected and analysed as a basis for understanding the } \\
\text { behaviour of, and to demonstrate the suitability and effectiveness of the process, and } \\
\text { to evaluate where continuous improvement of the process can be made. }\end{array}$} \\
\hline \multicolumn{2}{|r|}{ COBIT Definition } & $\begin{array}{l}\text { COBIT Process } \\
\text { Maturity level }\end{array}$ & $\begin{array}{l}\text { ISO/IEC } \\
15504 \text { Rating }\end{array}$ \\
\hline \multicolumn{2}{|c|}{ Goals are not clear and no measurement takes place. } & 1 & $\mathrm{~N}$ \\
\hline \multicolumn{2}{|c|}{$\begin{array}{l}\text { Some goal setting occurs; some financial measures are established but are } \\
\text { known only to senior management. There is inconsistent monitoring in isolated } \\
\text { areas. }\end{array}$} & 2 & $\mathrm{~N}$ \\
\hline \multicolumn{2}{|c|}{$\begin{array}{l}\text { Some effectiveness goals and measures are set, but are not communicated, and } \\
\text { there is a clear link to business goals. Measurement processes emerge, but are } \\
\text { not consistently applied. IT balanced scorecard ideas are being adopted as is } \\
\text { the occasional intuitive application of root cause analysis. IT balanced } \\
\text { scorecard ideas are being adopted as is the occasional intuitive application of } \\
\text { root cause analysis. }\end{array}$} & 3 & $\mathrm{P}$ \\
\hline \multicolumn{2}{|c|}{$\begin{array}{l}\text { Efficiency and effectiveness are measured and communicated and linked to } \\
\text { business goals and the IT strategic plan. The IT balanced scorecard is }\end{array}$} & 4 & $\mathrm{~L}$ \\
\hline
\end{tabular}


implemented in some areas with exceptions noted by management and root cause analysis is being standardised. Continuous improvement is emerging.

There is an integrated performance measurement system linking IT performance to business goals by global application of the IT balanced scorecard. Exceptions are globally and consistently noted by management and root cause analysis is applied. Continuous improvement is a way of life.

\section{COBIT process maturity rating model}

Table IIX lists the derived COBIT process maturity level in terms of the ratings for the ISO/IEC 15504 process attribute achievement results, and are transcribed from Tables I through to VII.

\begin{tabular}{|c|c|c|c|c|c|}
\hline \multicolumn{6}{|c|}{ Table IIX COBIT process maturity rating model } \\
\hline & \multicolumn{5}{|c|}{ COBIT Process Maturity Level } \\
\hline COBIT Process attribute & 1 & 2 & 3 & 4 & 5 \\
\hline CPA 1 Process performance & $\mathrm{P}$ & $\mathrm{L}$ & $\mathrm{F}$ & $\mathrm{F}$ & $\mathrm{F}$ \\
\hline $\begin{array}{l}\text { CPA } 2 \text { Responsibility and } \\
\text { accountability }\end{array}$ & $\mathrm{N}$ & $\mathrm{P}$ & $\mathrm{L}$ & $\mathrm{F}$ & $\mathrm{F}$ \\
\hline CPA 3 Awareness \& Communication & $\mathrm{N}$ & $\mathrm{P}$ & $\mathrm{L}$ & $\mathrm{F}$ & $\mathrm{F}$ \\
\hline CPA 4 Policies, Plans \& Procedures & $\mathrm{N}$ & $\mathrm{P}$ & $\mathrm{L}$ & $\mathrm{F}$ & $\mathrm{F}$ \\
\hline CPA 5 Tools \& Automation & $\mathrm{N}$ & $\mathrm{N}$ & $\mathrm{P}$ & $\mathrm{L}$ & $\mathrm{F}$ \\
\hline CPA 6 Skills \& Expertise & $\mathrm{N}$ & $\mathrm{P}$ & $\mathrm{L}$ & $\mathrm{F}$ & $\mathrm{F}$ \\
\hline CPA 7 Goal Setting \& Measurement & $\mathrm{N}$ & $\mathrm{N}$ & $\mathrm{P}$ & $\mathrm{L}$ & $\mathrm{F}$ \\
\hline
\end{tabular}

The COBIT process maturity level is a composite of minimum rating values.

Process maturity Level 1 will be attained provided that CPA 1 is rated at least Partially. The ratings of CPA 2 to CPA 7 can be rated None.

Process maturity Level 2 will be attained when CPA 1 is rated at least Largely, while CPA 2, 34 and 6 are rated at least Partially.

Process maturity Level 3 will be attained when CPA 1 is rated Fully, CPA 2, 34 and 6 are rated at least Largely, while CPA 5 and 7 must be rated at least Partially.

Process maturity Level 4 will be attained when CPA 1, 2, 34 and 6 are rated Fully, while CPA 5 and 7 must be rated at least Largely.

Process maturity Level 5 will be attained when CPA 1 though to 7 are all rated Fully.

\section{Process evidence that supports the COBIT process attributes ratings}

Table IX provides suggestions as to what is likely to be sources of evidence that underpins the ISO/IEC process attribute achievement results.

\begin{tabular}{|l|l|}
\hline \multicolumn{2}{|c|}{ Table IX Types of process evidence considered } \\
\hline \multicolumn{1}{|c|}{$\begin{array}{c}\text { ISO/IEC 15504 Process attribute } \\
\text { achievement result }\end{array}$} & \multicolumn{1}{c|}{ Nature of process evidence considered } \\
\hline $\begin{array}{l}\text { 1.1 a) the process achieves its defined } \\
\text { outcomes. }\end{array}$ & $\begin{array}{l}\text { This type of evidence is associated with the performance of COBIT } \\
\text { control objectives. }\end{array}$ \\
\hline
\end{tabular}




\section{Table IX Types of process evidence considered}

\begin{tabular}{|c|c|}
\hline $\begin{array}{l}\text { ISO/IEC } 15504 \text { Process attribute } \\
\text { achievement result }\end{array}$ & Nature of process evidence considered \\
\hline $\begin{array}{l}2.1 \text { a) objectives for the performance of the } \\
\text { process are identified; }\end{array}$ & $\begin{array}{l}\text { If there is a standard process, then these performance objectives are } \\
\text { likely to be identified in the process description. If the process supports } \\
\text { project-based activities, then this type of information might be } \\
\text { contained in the project plan. Alternatively, these objectives could be } \\
\text { located in meetings held to administer the process. }\end{array}$ \\
\hline $\begin{array}{l}2.1 \mathrm{~d} .1 \text { ) responsibilities and authorities for } \\
\text { performing the process are defined; }\end{array}$ & $\begin{array}{l}\text { This type of information is most likely to be found in job descriptions, } \\
\text { usually located in the human resource management process. If the } \\
\text { process supports project-based activities, then this type of information } \\
\text { might be contained in the project plan. }\end{array}$ \\
\hline $\begin{array}{l}2.1 \mathrm{~d} .2) \text { responsibilities and authorities for } \\
\text { performing the process are assigned and } \\
\text { communicated; }\end{array}$ & $\begin{array}{l}\text { These are likely to be held in a planning roster for the next process } \\
\text { performance cycle. If such a roster does not exist, then such } \\
\text { information might be located in minutes of meetings. }\end{array}$ \\
\hline $\begin{array}{l}2.1 \text { e.1) resources and information necessary } \\
\text { for performing the process are identified. }\end{array}$ & $\begin{array}{l}\text { If the process supports project-based activities, then this type of } \\
\text { information is likely to be found in the project plan. } \\
\text { In a mature process environment, these arrangements are likely to be } \\
\text { planned, and referred to in process descriptions. }\end{array}$ \\
\hline $\begin{array}{l}2.1 \text { e.2) resources and information necessary } \\
\text { for performing the process are made } \\
\text { available, allocated and used; }\end{array}$ & $\begin{array}{l}\text { The evidence of these arrangements is usually located in permissions } \\
\text { requested and granted to access repositories of controlled information. } \\
\text { Minutes of meetings are likely to be the alternative source. }\end{array}$ \\
\hline $\begin{array}{l}2.1 \mathrm{f} .1 \text { ) interfaces between the involved } \\
\text { parties are managed to ensure clear } \\
\text { assignment of responsibility. }\end{array}$ & $\begin{array}{l}\text { In a mature environment, this type of information is likely to be part of } \\
\text { the process descriptions. If the process supports project-based } \\
\text { activities, then this type of information might be contained in the } \\
\text { project plan or RACI charts in process descriptions. Failing that, } \\
\text { minutes of meetings are likely to be the alternative source. }\end{array}$ \\
\hline $\begin{array}{l}2.1 \mathrm{f} .2) \text { interfaces between the involved } \\
\text { parties are managed to ensure effective } \\
\text { communication. }\end{array}$ & $\begin{array}{l}\text { Normally, the planned arrangements for communication are the likely } \\
\text { source of this information. These arrangements are likely to refer to the } \\
\text { regular types of meetings to be held in the process cycle, or it may refer } \\
\text { to other formal channels of communication i.e. e-mail groups, } \\
\text { information portals etc. }\end{array}$ \\
\hline $\begin{array}{l}3.1 \text { a) a standard process, including } \\
\text { appropriate tailoring guidelines, is defined } \\
\text { that describes the fundamental elements that } \\
\text { must be incorporated into a defined process. }\end{array}$ & $\begin{array}{l}\text { The standard process is likely to include the following elements: policy } \\
\text { statement, process description, procedures, and templates. }\end{array}$ \\
\hline $\begin{array}{l}3.1 \text { c.1) required competencies for performing } \\
\text { a process are identified as part of the } \\
\text { standard process; }\end{array}$ & $\begin{array}{l}\text { These descriptions are likely to be located in the human resource } \\
\text { management process. }\end{array}$ \\
\hline $\begin{array}{l}3.1 \text { c. } 2 \text { ) required roles for performing a } \\
\text { process are identified as part of the standard } \\
\text { process; }\end{array}$ & $\begin{array}{l}\text { Normally described in the process description, typically summarised in } \\
\text { RACI charts. }\end{array}$ \\
\hline $\begin{array}{l}3.1 \mathrm{~d} \text { ) required infrastructure and work } \\
\text { environment for performing a process are } \\
\text { identified as part of the standard process; }\end{array}$ & $\begin{array}{l}\text { Normally described in the process description. It is not unusual to find } \\
\text { that process descriptions assume the availability of common elements } \\
\text { of IT infrastructure. Exceptional elements may be referred to - e.g. } \\
\text { special tools required. }\end{array}$ \\
\hline $\begin{array}{l}3.1 \text { e) suitable methods for monitoring the } \\
\text { effectiveness and suitability of the process } \\
\text { are determined. }\end{array}$ & $\begin{array}{l}\text { The process description will normally identify how the effectiveness of } \\
\text { the process is to be measured. }\end{array}$ \\
\hline
\end{tabular}




\section{Table IX Types of process evidence considered}

\section{ISO/IEC 15504 Process attribute achievement result}

$3.2 \mathrm{~b}$ ) required roles, responsibilities and authorities for performing the defined process are assigned and communicated;

$3.2 \mathrm{c}$ ) personnel performing the defined process are competent on the basis of appropriate education, training, and experience.

$3.2 \mathrm{~d}$ ) required resources and information necessary for performing the defined process are made available, allocated and used;

$3.2 \mathrm{e})$ required infrastructure and work environment for performing the defined process are made available, managed and maintained;

\section{$3.2 \mathrm{f}$ ) appropriate data are collected and} analysed as a basis for understanding the behaviour of, and to demonstrate the suitability and effectiveness of the process, and to evaluate where continuous improvement of the process can be made.
Nature of process evidence considered

This type of information is most often contained in job letters - in which the actual responsibilities and expected performance requirements are communicated to the individual.

Alternatively, if the process supports project-based activities, then this type of information is likely to be found in the project plan.

This type of information is most often contained in personnel development plans, with the performance against the plan being reviewed at regular intervals.

Appointment letters viewed in conjunction with the job requirements could be an alternative source.

The most sensitive indicator of performance in this area is the evidence of the actual assignment of resources (i.e. finance, people, information resources, tools) against budgeted requests.

The expectations for these concerns are normally identified in the process description. The need for infrastructure and work environment is often contained in the business case - which defines the service to be offered, the infrastructure and work environment, tools, staff establishment, and financial requirements for the next accounting period.

This provides the record of the data captured, analyses performed, and issues / improvements raised as a consequence of such process monitoring.

A likely source of evidence is a Process / Service Improvement Plan that draws on process measurement data and the analysis thereof to initiate improvement.

\section{Illustrative case study}

Table $\mathrm{X}$ brings together a set of sample ratings for a process (i.e. the ratings values of $\mathrm{N}, \mathrm{P}, \mathrm{L}$ and $\mathrm{F}$ ) and their associations with COBIT process attributes, as defined in Tables II to VII.

\begin{tabular}{|l|c|c|c|c|c|c|c|}
\hline \multicolumn{7}{|c|}{ Table X Evidence ratings and associations with COBT process attributes } \\
\hline $\begin{array}{c}\text { ISO/IFC 15504 Process attribute } \\
\text { achievement result }\end{array}$ & CPA 1 & CPA 2 & CPA 3 & CPA 4 & CPA 5 & CPA 6 & CPA 7 \\
\hline $\begin{array}{l}\text { 1.1 a) the process achieves its defined } \\
\text { outcomes. }\end{array}$ & F & & & & & & \\
\hline $\begin{array}{l}\text { 2.1 a) objectives for the performance of } \\
\text { the process are identified; }\end{array}$ & & & & & & & F \\
\hline $\begin{array}{l}\text { 2.1 d.1) responsibilities and authorities } \\
\text { for performing the process are defined } \\
\text { and assigned; }\end{array}$ & & F & & & & & \\
\hline $\begin{array}{l}\text { 2.1 d.2) responsibilities and authorities } \\
\text { for performing the process are } \\
\text { communicated; }\end{array}$ & & & F & & & & \\
\hline
\end{tabular}


Table X Evidence ratings and associations with COBIT process attributes

\begin{tabular}{|c|c|c|c|c|c|c|c|}
\hline $\begin{array}{l}\text { ISO/IEC } 15504 \text { Process attribute } \\
\text { achievement result }\end{array}$ & CPA 1 & CPA 2 & CPA 3 & CPA 4 & CPA 5 & CPA 6 & CPA 7 \\
\hline $\begin{array}{l}2.1 \text { e.1) resources and information } \\
\text { necessary for performing the process are } \\
\text { identified. }\end{array}$ & & & $\mathrm{F}$ & & F & & \\
\hline $\begin{array}{l}2.1 \text { e.2) resources and information } \\
\text { necessary for performing the process are } \\
\text { made available, allocated and used; }\end{array}$ & & & $\mathrm{F}$ & & $\mathrm{F}$ & & \\
\hline $\begin{array}{l}2.1 \text { f.1) interfaces between the involved } \\
\text { parties are managed to ensure clear } \\
\text { assignment of responsibility. }\end{array}$ & & F & F & & & & \\
\hline $\begin{array}{l}2.1 \mathrm{f} .2) \text { interfaces between the involved } \\
\text { parties are managed to ensure effective } \\
\text { communication. }\end{array}$ & & & $\mathrm{F}$ & & & & \\
\hline $\begin{array}{l}3.1 \text { a) a standard process, including } \\
\text { appropriate tailoring guidelines, is } \\
\text { defined that describes the fundamental } \\
\text { elements that must be incorporated into a } \\
\text { defined process. }\end{array}$ & & & & L & & & \\
\hline $\begin{array}{l}3.1 \text { c.1) required competencies for } \\
\text { performing a process are identified as } \\
\text { part of the standard process; }\end{array}$ & & $\mathrm{F}$ & & & & F & \\
\hline $\begin{array}{l}3.1 \text { c. } 2 \text { ) required roles for performing a } \\
\text { process are identified as part of the } \\
\text { standard process; }\end{array}$ & & $\mathrm{F}$ & & & & & \\
\hline $\begin{array}{l}3.1 \mathrm{~d} \text { ) required infrastructure and work } \\
\text { environment for performing a process are } \\
\text { identified as part of the standard } \\
\text { process; }\end{array}$ & & & & & $\mathrm{P}$ & & \\
\hline $\begin{array}{l}3.1 \text { e) suitable methods for monitoring } \\
\text { the effectiveness and suitability of the } \\
\text { process are determined. }\end{array}$ & & & & & & & F \\
\hline $\begin{array}{l}3.2 \mathrm{~b} \text { ) required roles, responsibilities and } \\
\text { authorities for performing the defined } \\
\text { process are assigned and communicated; }\end{array}$ & & $\mathrm{F}$ & & & & & \\
\hline $\begin{array}{l}3.2 \text { c) personnel performing the defined } \\
\text { process are competent on the basis of } \\
\text { appropriate education, training, and } \\
\text { experience. }\end{array}$ & & & & & & $\mathrm{L}$ & \\
\hline $\begin{array}{l}3.2 \mathrm{~d} \text { ) required resources and information } \\
\text { necessary for performing the defined } \\
\text { process are made available, allocated and } \\
\text { used; }\end{array}$ & & & & & $\mathrm{P}$ & & \\
\hline $\begin{array}{l}3.2 \text { e) required infrastructure and work } \\
\text { environment for performing the defined } \\
\text { process are made available, managed and } \\
\text { maintained; }\end{array}$ & & & & & $\mathrm{F}$ & & \\
\hline
\end{tabular}


Table X Evidence ratings and associations with COBIT process attributes

\begin{tabular}{|c|c|c|c|c|c|c|c|}
\hline $\begin{array}{c}\text { ISO/IFC 15504 Process attribute } \\
\text { achievement result }\end{array}$ & CPA 1 & CPA 2 & CPA 3 & CPA 4 & CPA 5 & CPA 6 & CPA 7 \\
\hline $\begin{array}{l}\text { 3.2 f) appropriate data are collected and } \\
\text { analysed as a basis for understanding } \\
\text { the behaviour of, and to demonstrate the } \\
\text { suitability and effectiveness of the } \\
\text { process, and to evaluate where } \\
\text { continuous improvement of the process } \\
\text { can be made. }\end{array}$ & & & & & & & F \\
\hline Aggregated CPA ratings & F & F & F & L & L & L & F \\
\hline $\begin{array}{l}\text { Overall COBIT process maturity level } \\
\text { (using Table IIX) }\end{array}$ & & & 3 & & & \\
\hline
\end{tabular}

The ratings for each COBIT process attribute are aggregated in the columns according the aggregation rationale associated with Table XI.

The final step is the computation of the overall COBIT process maturity level by applying the rules defined in Section 5 . In this simple example, there are weaknesses associated with CPA 4, 5 and 6. To achieve a process maturity rating of 4, for example, the weaknesses associated with CPA 4 and 6 will need to be addressed, in order to improve the ratings from Largely to Fully.

\section{Discussion}

8.1 The use of the higher capability ISO/IEC 15504 process attributes in computing the COBIT process maturity level

Use of the ISO/IEC 15504 Level 4 and 5 process attribute achievement results have not been used in the computation of the COBIT process maturity levels. It could be argued that the COBIT Goals and Measurement process attribute could benefit from the inclusion of at least some of the ISO/IEC 15504 PA 4.1 achievement results. These have not been included in this proposed model since the primary emphasis in the Section 4.7 COBIT definitions is upon process effectiveness. Some of the Level 5 concerns (i.e. Exceptions are globally and consistently noted by management and root cause analysis is applied. Continuous improvement is a way of life.) are believed to be misplaced - they would be better associated with an improvement process.

\subsection{Assessment type in relation to COBIT and ISO/IEC 15504 assessments}

ISO/IEC 15504 Part 7 (ISO, 2007) refers to three assessment classes, namely Types 1, 2 and 3 . Type 1 is associated with most rigour in terms of assessment conduct and gathering of process evidence, while Type 3 is the least rigorous.

Regarding the use of the assessment approach to computing the COBIT process maturity, it is considered that it is most suited in those conditions where the highest assessment rigour is required e.g. where a demonstration of the attainment of a mandated COBIT process maturity level is identified as part of a contractual obligation.

The assessment approaches described in (Simonsson, 2007) and (Pederiva,2003) is considered adequate for performing Type 3 assessments.

\section{References}

International Organization for Standardization, (2003), ISO/IEC 15504-2, "Information Technology — Process Assessment — Part 2: Performing an assessment"

International Organization for Standardization, (2005), ISO/IEC 15504-5, "Information Technology — Process Assessment — Part 5: An exemplar process assessment model"

International Organization for Standardization, (2008), ISO/IEC 15504-7, "Information technology — Process assessment — Part 7: Assessment of Organizational Maturity" 
"COBIT 4.1 Control Objectives for Information Technology", (2007), IT Governance Institute, http://www.itgi.org

Pederiva, A (2003), "The COBIT Maturity Model in a Vendor Evaluation Case", Information Systems Control Journal, Vol. 4.

Simonsson, M. (2007), "Model-Based IT Governance Maturity Assessments With COBIT", www.ee.kth.se/php/modules/publications/reports/2007/IR-EE-ICS 2007 026.pdf (Accessed 29 December 2010)

\section{Appendix A:}

\section{A.1 Process attribute rating scale}

\begin{tabular}{|c|c|c|}
\hline \multicolumn{3}{|c|}{ Table XI ISO/IEC 15504 rating scale } \\
\hline Rating & Definition & $\begin{array}{l}\text { Measurement } \\
\text { Scale }\end{array}$ \\
\hline Fully & $\begin{array}{l}\text { There is evidence of a complete and systematic approach to, and full achievement of, } \\
\text { the defined attribute in the assessed process. No significant weaknesses related to this } \\
\text { attribute exist in the assessed process. }\end{array}$ & $86 \%$ to $100 \%$ \\
\hline Largely & $\begin{array}{l}\text { There is evidence of a systematic approach to, and significant achievement of, the } \\
\text { defined attribute in the assessed process. Some weakness related to this attribute may } \\
\text { exist in the assessed process. }\end{array}$ & $51 \%$ to $85 \%$ \\
\hline Partially & $\begin{array}{l}\text { There is some evidence of an approach to, and some achievement of, the defined } \\
\text { attribute in the assessed process. Some aspects of achievement of the attribute may be } \\
\text { unpredictable. }\end{array}$ & $16 \%$ to $50 \%$ \\
\hline None & $\begin{array}{l}\text { There is little or no evidence of achievement of the defined attribute in the assessed } \\
\text { process. }\end{array}$ & $0 \%$ to $15 \%$ \\
\hline
\end{tabular}

